\title{
EFFECTS OF ORGANIZATIONAL-PROFESSIONAL CONFLICT AND AUDITOR BURNOUT ON DYSFUNCTIONAL AUDIT BEHAVIOUR
}

\author{
Tabita Indah ISWARI ${ }^{1 *}$
}

\begin{abstract}
Received: March 2020 | Accepted: November 2020 | Published: December 2020
Please cite this paper as: ISWARI, T.I. (2020) Effects of Organizational-Professional Conflict and Auditor Burnout on Dysfunctional Audit Behaviour, Holistica Journal of Business and Public Administration, vol. 11, iss. 3, pp.102-119
\end{abstract}

\begin{abstract}
Auditors are expected to provide a good quality in auditing performance. However, in practice, some conditions may impair the auditors' professional behaviour. The conflict between professional and organizational values that may occur during the auditing process may become a dilemma for the auditor as a professional. This condition eventually can make the auditor to have a dysfunctional behaviour in performing audit. Some studies showed that the phenomenon of dysfunctional audit behaviour is also correlated to the job burnout the auditor experiences in performing the audit fieldwork. This study, in turn, examined the effects of organizational professional conflict (OPC) and auditor burnout on dysfunctional audit behaviour. It was hypothesized that both OPC and auditor burnout have the positive effects on dysfunctional audit behaviour. Data collection in this study was performed by distributing the questionnaires through the survey method sent to the respondents, i.e. 79 auditors working in public accounting firm using the convenience sampling technique. The results of this study indicated that job burnout, as hypothesized, had positive effect on dysfunctional audit behaviour; while the OPC had no effect on dysfunctional audit behaviour.
\end{abstract}

Keywords: Organizational - Professional Conflict; Auditor Burnout; Dysfunctional Audit Behaviour

\section{Introduction and Research Background}

The reliability of the financial statement reporting is crucial to its users for making some financial decisions based on the information in the financial statements. It is undeniable that audited financial statements have more values regarding its reliability compared to the unaudited one. In relation to the Enron Corporation case, as one of the biggest accounting scandals, followed by the establishment of Sarbanes-Oxley Act of 2002 (SOX 2002), the public accountant profession becomes more concern about its performance in making the assessment towards the fairness of financial statement. The International Standards on Auditing (ISA), as the latest standard on auditing, emphasizes that investor

\footnotetext{
1* Corresponding author. Accounting Department, Faculty of Business and Economics, Universitas
} Atma Jaya Yogyakarta, Indonesia, E - mail: tabita.iswari@uajy.ac.id. 
should get the value - added information from the financial statement to make a better decision. It requires that public accountant profession should improve their quality in performing the audit. A public accounting firm in providing their assurance should be enhanced with the quality control system within their organization to mitigate the probability of unethical behaviour in assurance services given. International Standard on Quality Control (ISQC) 1.11 and International Standard on Auditing (ISA) 220 states that an accounting firm should establish, maintain, and implement a system of quality control to ensure that the audit services given is complied with professional standard, applicable legal, and regulatory requirements, and to ensure the appropriateness of the audit report issued (Tuanakotta, 2014; https://www.ifac.org/system/files/downloads/a007-2010iaasb-handbook-isqc-1.pdf; https://www.ifac.org/system/files/downloads/a010-2010iaasb-handbook-isa-220.pdf ).

It is commonly known that auditor is the independent third party who makes the assessment toward the fairness of the financial statement in purpose to mitigate the risk of information bias from the management due to potential conflict of interest between principal and agent. Auditor provides the assurance service to ascertain that management financial information is reliable for its user to make the decision. As explained previously, ISQC 1.11 and ISA 220 clearly stated that auditors should work in a system of quality control and may not perform any kind of behaviour that may impair the quality of audit work.

In purpose to provide the objective opinion toward the fairness of financial statement as a work outcome, auditors should perform their work in good quality. Providing the good quality in performing the audit requires both of competency and ethical behaviour from the auditor. It may occur in the very beginning of audit process. For example, when accounting firm is going to make audit engagement with its client, there are some assessments toward auditors' competency and independency (Boynton and Johnson, 2006).

At workplace, employee may experience conflict and job stress (Luthans, 2012). Regarding the conflict, it may rise from the different values adopted by the professionals. As a professional, there are some values adopted while performing professional services. On the other hand, the organizations that employ the professional also adopt some values. However, in practice, auditor as a professional may face some conditions in which organization values are not in accordance with the values adopted as a professional. In this phenomenon, it can be said that organizational and professional norms and values are inherently incompatible (Blau \& Scott, 1962 as cited in Aranya \& Ferris, 1984). Furthermore, this situation may cause dilemma within the auditors while they are assigned in a fieldwork. This condition may raise the opportunity of conflict within the auditor itself that may lead to the unethical behaviour.

The other condition that may be faced by the auditor is the stressful workplace that may cause auditor experience job stress. Being engaged in an assignment at audit fieldwork could be so stressful for the auditor. The job stress in accounting profession is not the 
HOLISTICA Vol 11, Issue 3, 2020, pp.102-119

latest issue and accounting is considered as a high-stress profession (Gaertner \& Ruhe, 1981). The unrelieved job stress in the further level may lead auditor to experience job burnout. In this situation, can be presumed that job burnout, as one of job stress type, may result into dysfunctional behavioural performance. Furthermore, it will lead auditor to reduce the quality in performing the audit (Ivancevich, et. al., 2014; Utami \& Nahartyo, 2013).

Based on those background conditions, this study examined the effect of organizational professional conflict, as a variable that defines the conflicting condition between organizational and professional values, and auditor burnout - a condition when the auditor experiences pressure and unrelieved job stress, on dysfunctional audit behaviour as the performance outcome caused by those two factors.

\section{Literature Review}

\subsection{Cognitive Dissonance Theory and Role Theory}

The cognitive dissonance theory was originally developed by Festinger in 1957 (HarmonJones, et. al, 2015). It is explained that the psychological discomfort or dissonance may occur when individuals have to cognitions that are relevant but inconsistent one to another (Harmon-Jones, et. al, 2015). Moreover, it is explained that according to this theory, individuals in order to avoid the mental discomfort, will change their preferences to more closely align with their actions while experiencing mental discomfort after taking actions that are conflicting with their starting preferences (Acharya, et.al, 2018). Ivancevich, et.al. (2014) clearly explained that in the situation of dissonance, there is a lack of consistency among the various cognitions. In this situation, the decision makers will feel doubt and have second thoughts about the choice they made since there is a conflict in what they know and believe and what was done (Ivancevich et.al, 2014).

Based on some previous studies as cited in Harmon-Jones, et.al (2015), there are some procedures that usually used in the test of this theory: induced - compliance paradigm that explains that individuals experience dissonance when they in the action with the high choice but they have little justification for doing so; free-choice or difficult paradigm that explains the dissonance occurs when the positive characteristics of the rejected option and negative characteristics of chosen options are inconsistent with the decision; and effort - justification paradigm that explains that dissonance results from inconsistency between unpleasant effort and the desire not to exert effort. This is clearly that in those procedures, when dissonance occurs, individuals will tend to reduce it. Furthermore, Harmon - Jones et.al (2015) explained that the situations that involve difficult decisions and a commitment to action can cause dissonance.

Meanwhile, according to the role theory, individual is expected to behave based on some characteristic (Biddle, 1986). Furthermore, it is explained that people will behave based on triad of concepts: patterned and characteristic social behaviours, assumptions by social 
HOLISTICA Vol 11, Issue 3, 2020, pp.102-119

participants that being identities to individuals, and expectations for behaviour adhered to by performers. The role theorists basically assume the expectation of behaviour based on norms, beliefs and preferences. The expectation of behaviour then depends on the mode of expectation assumed since there will be different reason and versions (Biddle, 1986).

The theory of cognitive dissonance and role theory are strongly related to the condition while there are conflicts between organizational and professional values. The professionals should obey to the professional values, however, in the same time, they are directed under the organizational values that may inconsistent with the professional values. In accordance with role theory, it can be explained that auditor has two roles: as a professional, which is directed under the Code of Professional Ethics; and a member of organization in which each role brings its own values (Utami, 2007). If this condition occurs, it may cause the mental discomfort in individuals and may affect their actions in practice.

\subsection{Organizational - Professional Conflict (OPC)}

Conflict is a state of mind that can be happened since there are difference in interests and values. It is commonly presumed that all conflict has negative effect and should be eliminated. Conflict may occur in several levels: intra-individual, interpersonal, intergroup, and organizational. In an organization, conflict could be functional or dysfunctional, which means that conflict actually have either positive of negative effects. Regarding organizational performance, it may also depend on the level of conflict. When the level of conflict is too low, it can suffer the organizational performance. It also resulting in chaos when the level of conflict is too high (Huczynski and Buchanan, 2007; Luthans, 2011; Ivancevich., et. al, 2014).

Some studies as cited in Shafer, et.al. (2002) explained that professionals have consequences to protect public interest and have to maintain their professional services on high standard of quality. To maintain their quality in professional services, the professionals are required to pursue professional education and certification and also commitment to high moral and ethical standard. When there are conflicts that may subordinate the public interest, they are not allowed to prioritize their personal gain towards public interest (Shafer, 2002).

Specifically, in an organization that employ the professionals, conflict may also occur since some values adopted in organization may inconsistent with professional values in practice. Some literatures generally defined organizational - professional conflict (OPC) as a conflict between organizational and professional values (Aranya \& Ferris, 1984; Shafer, Park, \& Liao, 2001; Shafer, 2002; Utami, 2007). Sorensen (1967) as cited in Aranya \& Ferris (1984) explained that in an organization, there are two kinds of behaviours that may occur: professionally-directed behaviour that presumably dictated by a code of ethics and organizationally-directed behaviour that controlled by directives issued by an employing organization. Later on, it is explained that this kind of conflict should not arise while organization-directed behaviour is consistent with the ethical code, but sometimes, 
the two sets of behaviour need not always coincide, and further, the professional may be forced to subrogate one set of behaviour to other. If this condition occurs, it may lead to the values conflict (Sorensen, 1967 as cited in Aranya \& Ferris, 1984).

In accounting profession, the professionals may experience this kind of conflict (Shafer, 2002). Some studies as cited in Shafer (2002) explained that in professional workplace, bureaucratic or organizational pressures would impair professionals' integrity and objectivity especially when professional services have been offered in other forms of organization, for example in a private corporation. Auditors or specifically, public accountants (Certified Public Accountants or CPAs), that work in public accounting firm are also directed by those values: professional values, as a member of professional association, and organizational values, as a member of public accounting firm. Same like in the other organizations, the conflict between those values (organizational and professional values) may occur in a public accounting firm.

\subsection{Auditor Burnout}

Working people sometimes experience burnout while performing their job, including the professionals. When an employee feels exhausted emotionally and experience cynicism in frequent that could be the symptoms of burnout (Maslach \& Jackson, 1981). Other aspects of burnout syndrome mentioned in Maslach and Jackson (1981) are: cynical attitude and feelings about one's client; and the other one is tendency to evaluate someone in negative ways. In detail, when people in a psychological condition and experience such feeling like: suffer from emotional exhaustion, lack of personal accomplishment, and tendency to depersonalize other; it can be also the burnout symptoms (Freudenberger, 1974 as cited in Utami \& Ertambang 2013). Furthermore, it is explained that burnout does not occur internally, but comes from social environment in which people work, and creates a sense of isolation and a feeling of lost control (Maslach in Cole, 1999 as cited in Luthans, 2011).

As mentioned previously, burnout can be also defined as unrelieved stress and it is believed that it has dysfunctional consequences for behavioural performance (Ivancevich, et. al., 2014; Utami \& Nahartyo, 2013). Emotional and interpersonal stressor form long term exposure of demanding situations may cause burnout in workplace that appears in employees' behaviour: lack of energy and enthusiasm (Larson, 2011 as cited in Utami \& Nahartyo, 2013). In a job - related stress concept contains three parts: the condition or stressor; the strain as effect to individuals, psychology, physics, and behaviour due to the stressor; and outcome as the result (Cooper, et. al, 2001 as cited in Umar, et. al, 2017).

It is commonly believed that burnout will bring negative effect on individual. Burnout can result in emotional exhaustion, depersonalization, and feeling of decreased accomplishment (Ivancevich, et, al., 2014). The indicators of burnout can be seen at the following table:

Table 1 The Indicator of Burnout 
HOLISTICA Vol 11, Issue 3, 2020, pp.102-119

Burnout Indicator

\begin{tabular}{|c|c|c|}
\hline Emotional Exhaustion & Depersonalization & Low Personal Accomplishment \\
\hline Feel drained by work & $\begin{array}{l}\text { Have become calloused by } \\
\text { job }\end{array}$ & $\begin{array}{c}\text { Cannot deal with problems } \\
\text { effectively }\end{array}$ \\
\hline $\begin{array}{l}\text { Feel fatigue in the } \\
\text { morning }\end{array}$ & $\begin{array}{c}\text { Do not care what happens to } \\
\text { other people }\end{array}$ & $\begin{array}{c}\text { Do not have positive influence on } \\
\text { others }\end{array}$ \\
\hline Frustrated & Feel other blame you & $\begin{array}{l}\text { Cannot understand others' } \\
\text { problem or identify with them }\end{array}$ \\
\hline $\begin{array}{l}\text { Do not want to work } \\
\text { with other people }\end{array}$ & & $\begin{array}{l}\text { No longer feel exhilarated by your } \\
\text { job }\end{array}$ \\
\hline
\end{tabular}

Source: Ivancevich, et.al, 1990 as cited in Ivancevich, et.al, 2014

Accounting job and the condition in accounting - professional workplace could be stressful as well as another professional job. In a public accounting firm, the auditors that have not pursue the partnership level, may experience stressful condition trough up-orout proposition. The audit fee, for example, could be the trigger for this stressful condition, as of the client could be very demanding that may lead auditors to pressure condition since they only have less time to accomplish their work (Gaertner \& Ruhe, 1981). The conditions such when the auditors have no control over their work, or in other condition, when the audit job demand exceeds auditors' abilities, it could be the negative stressor that may lead them to experience burnout (Utami \& Ertambang, 2013).

\subsection{Dysfunctional Audit Behaviour}

Some previous studies (Sweeney and Pierce, 2004; Bedard, et.al, 2008; Paul, et.al, 2003) as cited in Khan et al. (2015) explained the term of dysfunctional audit behaviour in several definition: the action that brings negative consequences for the firm, auditor itself, and entire profession, done intentionally; anti - social behaviour; improper verification in sampling method and acceptance of questionable evidence by auditors. For example, auditor may agree with the doubtful evidence or select the wrong sample test while performing the audit test (Allen \& Lee, 2002 as cited in Khan, 2015). This kind of mistakes may be done by the auditors who do not understand the demand of their work, or may be caused by their incompetence (Donnely, 2002 a s cited in Khan, 2015). Another previous studies (Nor, 2011; Baldachinno, 2016) as cited in Umar, et.al. (2017) explained that dysfunctional audit behaviour that could result on audit failure occur when auditor hard to identify material misstatement in their clients' financial statement.

Sweeney and Pierce (2004) as cited in Khan (2015) stated that when the auditors compromise regarding the reliability of audit evidence, dysfunctional audit behaviour take the form of action during that process. Furthermore, study by Khan (2015) used two form of dysfunctional audit behaviour: premature sign - off (PMSO) and underreporting of time (URT). Premature sign - off is explained as a condition when the auditors, for some reasons (e.g.: deadline pressure; recognition of audit step; lack of training and experience; laziness and boredom) will sign - off on required procedures without completing required 
HOLISTICA Vol 11, Issue 3, 2020, pp.102-119

audit procedures (Sweeney \& Pierce, 2004; Rhodes, 1978; as cited in Khan, 2015). Meanwhile, underreporting of time is the desire to avoid or minimize budget over-runs (Otley and Pierce, 1996 as cited in Khan, 2015). Some literatures cited in Khan (2015) explained that in this condition could lead to compromised audit environment or even audit disaster since the senior staff might provide poor audit quality and manipulate audit evidence.

Some studies (Silaban, 2009; Donnelly, 2003) also identified another dysfunctional behaviour that could be happen in performing audit: reduced audit quality behaviour (RAQ) and altering audit procedures. Some previous studies (Kelley \& Margheim, 1990; Malone \& Rober, 1996; Otley \& Pierce, 1996; Pierce \& Sweeney, 2004) as cited in Silaban (2009) defined reduced audit quality behaviour as every single action done by the auditors in performing audit procedures which directly reduced the audit quality. Meanwhile, Donnelly (2003) considered altering or reducing audit procedures a dysfunctional behaviour that might be accepted by the auditors in performing audit.

\subsection{Relation of Organizational - Professional Conflict and Dysfunctional Audit Behaviour}

As workplace is the place that conflict between employee and managers (as the representative of owner or founder) may occur, the consequence may arise. Due to the occurrence of conflict, Huczynzki and Buchanan (2007) use the term organizational misbehaviour to mark anything that workers do in workplace which they are not supposed to do. Brought to the term used in this study, it can be concluded that the conflict among professional and organizational values may also presumed to result on dysfunctional behaviour.

Some previous studies (Aranya \& Ferris, 1984; Shafer, 2002) explained that there are relations of organizational - professional conflict and organizational outcomes, either positive or negative (job satisfaction and turnover intentions) among accountants as professionals. Turnover intentions as a negative effect caused by organizational professional conflict bring positive relation among both variables (Aranya \& Ferris, 1984; Shafer, 2002). In the context of conflict between professional and organizational values that may occur in a public accounting firm, dysfunctional audit behaviour can be also considered as negative effect due to the conflict.

The study by Paino, et.al (2011) found that there is a negative effect of organizational commitment on dysfunctional audit behaviour. High level of organizational commitment will be associated with low level of dysfunctional behaviour. In this case, organizational commitment related to the positive behaviour since the organizational commitment encourage employee to accept organization goals and willingness to do some efforts on behalf of organization. Reversely, it can be presumed that organizational - professional conflict as a negative trigger may lead employees or specifically, the professionals, to the dysfunctional behaviour. 
HOLISTICA Vol 11, Issue 3, 2020, pp.102-119

Based on the previous finding, the relation of organizational-professional conflict and dysfunctional audit behaviour can be hypothesized as follow:

H1: Organizational - professional conflict has positive effect on dysfunctional audit behaviour.

\subsection{Relation of Auditor Burnout and Dysfunctional Audit Behaviour}

Some literatures (Gaertner \& Ruhe, 1981; Ivacevich, et.al, 2014) explained that stress in a workplace can have negative effect on individuals' aspect: productivity, effectiveness, and personal health; and it may also cost organization money due to some consequences, including: reduction in operation effectiveness, poorer decision making and decreases in activity. Moreover, job - related stress may also have physical consequences that lead to organizational consequences, for example on job performance (Gaertner \& Ruhe, 1981). Many factors are presumed to affect the occurrence of dysfunctional behaviour in audit assignment, including job - related stress that presume could change individual's behaviour (Umar, et.al., 2017).

Donelly (2003) explained that prior literature had identified that environmental factor (for example: time pressure) affected dysfunctional behaviour. Utami and Ertambang (2018) explained that dysfunctional consequences in behavioural performance are caused only by burnout as the one of type of job stress. In other hands, it is said that auditor can respond pressure in two ways: functional or dysfunctional behaviour (Mcnamara \& Liyanarachchi, 2008) as cited in Umar, et.al, 2017). Furthermore, study by Mcnamara and Liyanarachchi (2008) and Coram, et.al. (2004) as cited in Umar, et.al (2017) explained that stressor caused by pressure has an impact that there will be dysfunctional behaviours done by auditor.

Another study by Yuen et.al (2013) regarding some factors (task complexity, time budget pressure, client importance, and auditor independence) affecting dysfunctional audit behaviour. Time budget pressure has positive effect on the acceptance of dysfunctional behaviour (Yuen, et.al, 2013). Burnout itself is the respond toward job pressure (Codes and Dougherty, 1993 as cited in Utami \& Ertambang, 2013). So, it can be presumed that burnout can affect the dysfunctional behaviour among auditors.

From some explanations above, it can be concluded that the condition of burnout that may occur among the professionals while they are performing the job may also cause on dysfunctional behaviour. Based on the previous study findings, the relation of auditor burnout and dysfunctional audit behaviour can be hypothesized as follow:

H2: Auditor burnout has positive effects on dysfunctional audit behaviour.

\section{Tables}

\subsection{Population and Sample}


HOLISTICA Vol 11, Issue 3, 2020, pp.102-119

Population on this study is the auditors that work in public accounting firm. Sample of the respondents is the auditors from the public accounting firm in this following city: Semarang, Solo, and Yogyakarta. Convenience sampling method is used for gathering the survey data in this study. Questionnaires are sent to auditors from 11 (eleven) public accounting firms in Semarang, Solo, and Yogyakarta that participate in the survey. 90 (ninety) questionnaires are sent, 82 (eighty-two) questionnaires are sent back (respond rate $96 \%$ ), and 79 (seventy-nine) questionnaires are able to be processed statistically $(\mathrm{N}=79)$.

\subsection{Research Model}

Based on the hypothesis developed, the research model in this study can be seen in the following figure:

Figure 1 Research Model

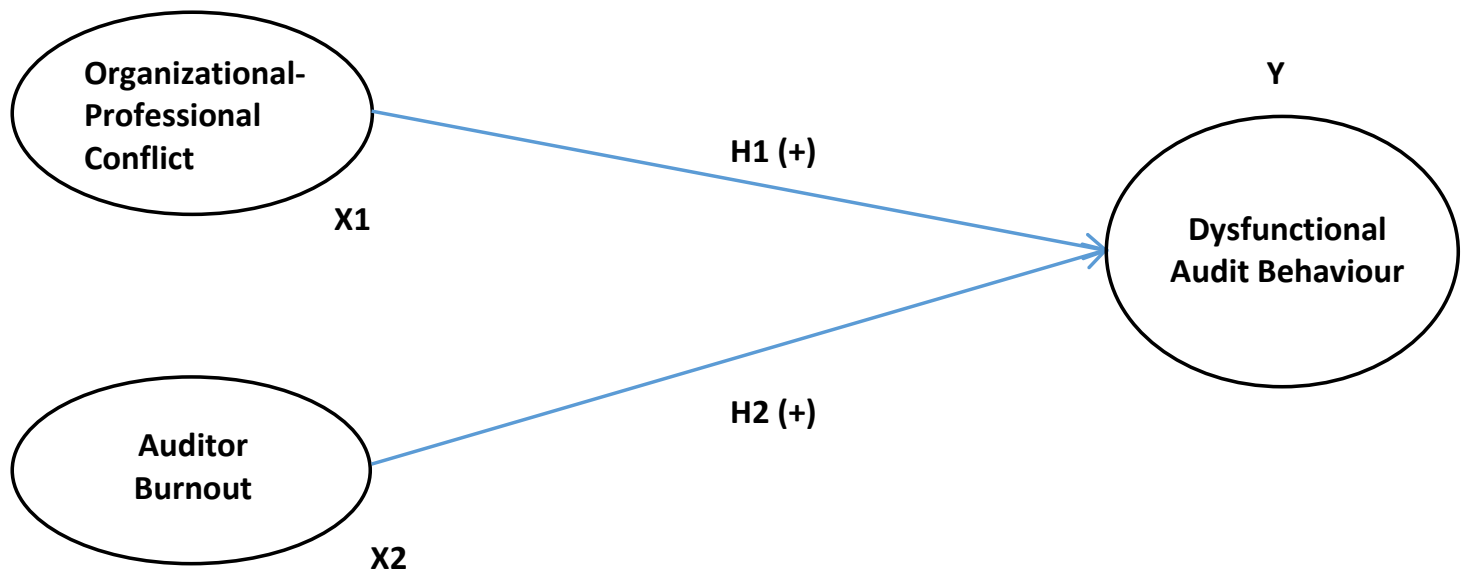

Source: Author's synthesis

\subsection{Variable Measurement}

There are two independent variables and one dependent variable that used in this study. Independent variables are the variables that influence positively and negatively the dependent variable (Sekaran \& Bougie, 2013). The first independent variable is organizational - professional conflict. The measurement of organizational - professional conflict is based on the modified instrument by Aranya and Ferris (1984) as cited in Shafer (2002). There are 3 (three) instrument items to be used as measurement for organizational - professional conflicts. The second independent variable is auditor burnout. The measurement of job burnout used the instrument by Maslach and Jackson (1981) as cited in Mas'ud (2004). There are 18 (eighteen) instrument items used in this study. 
Moreover, the dependent variable is the variable that being the main interest for the researcher to be understood and described (Sekaran \& Bougie, 2013). The dependent variable used in this study is dysfunctional audit behaviour. The measurement is based on some dysfunctional behaviour in performing the audit assignment: reduced audit quality behaviour, underreporting of time, premature sign-off, and altering audit procedures. 10 (ten) instrument items for reduced audit quality behaviour and 3 (three) instrument items for underreporting of time are measured using the instrument by Silaban (2009). 10 (ten) instrument items for premature sign-off toward audit procedures are measured using the instrument by Weningtyas, et.al (2006). 4 (four) instrument items for altering audit procedures is measured using the modified instrument based on instrument by Donnelly, et.al (2003). All of the instrument items for dysfunctional audit behaviour are measured using $1-5$ Likert scale.

\subsection{Instrument Reliability and Validity Test}

All of the instrument items should be tested for its reliability and validity. Validity test is performed to check the goodness of a developed instrument measure the concept, in the other hand; reliability test is a test for the consistency of an instrument to measure the concept (Sekaran and Bougie, 2013).

The Cronbach Alpha statistic test is used to test the instrument reliability in this study. A construct or variable is variable if the value of Cronbach Alpha is $>0.70$ or more than 0.70 (Nunnally, 1994 as cited in Ghozali, 2011). The result of the reliability test can be seen in the following table:

Table 2 Reliability test for independent and dependent variables

\begin{tabular}{cccc}
\hline Variables & $\begin{array}{c}\text { Cronbach's } \\
\text { Alpha }\end{array}$ & $\begin{array}{c}\text { Cronbach's Alpha Based on } \\
\text { Standardized Items }\end{array}$ & $\begin{array}{c}\text { N of } \\
\text { Items }\end{array}$ \\
\hline $\begin{array}{c}\text { Dysfunctional Audit } \\
\text { Behaviour } \\
\begin{array}{c}\text { Organizational - } \\
\text { Professional Conflict } \\
\text { Auditor Burnout }\end{array}\end{array}$ & .981 & .982 & 27 \\
\hline
\end{tabular}

Source: SPSS output, processed primary data, 2019

From the reliability test result, as can be seen, the value of Cronbach's Alpha for dysfunctional audit behaviour variable is 0.982; for organizational - professional conflict variable is 0.746; and for auditor burnout variable is 0.905 . Based on the criteria by Nunnally (1994) as cited in Ghozali (2011) all of the variables are reliable.

Validity test in this study is performed by KMO and Bartlett's test. The instrument items should have the expected KMO values is more than $0.5(>0.50)$, so the factor analysis can be continued (Ghozali, 2011). The result of KMO and Bartlett's test can be seen on this following table: 
Table 3 Validity test using KMO and Bartlett's Test

\begin{tabular}{cc}
\hline \multicolumn{3}{c}{ KMO and Bartlett's Test } \\
\hline Kaiser-Meyer-Olkin Measure of Sampling Adequacy & .851 \\
Bartlett's Test of Sphericity Approx. Chi-Square & $4.414 \mathrm{E} 3$ \\
df & 1128 \\
Sig. & .000
\end{tabular}

Source: SPSS output, processed primary data, 2019

From the table, it can be seen that the KMO value is 0.851 . Based on the criteria from Ghozali (2011), it can be concluded that factor analysis can be done, and the requirement for instrument validity is fulfilled.

\subsection{Normality and Classical Assumption Test}

The normality test is performed to test whether the residual is normally distributed using the Kolmogorov - Smirnov test. The result for normality test can be seen in the following table:

Table 4 The Result of Normality Test

\begin{tabular}{ccc}
\hline & \multicolumn{2}{c}{ One-Sample Kolmogorov-Smirnov Test } \\
\hline \multicolumn{2}{c}{$\mathrm{N}$} & Unstandardized Residual \\
\hline Normal Parameters ${ }^{\mathrm{a}}$ & Mean & 79 \\
& Std. Deviation & .0000000 \\
Most Extreme Absolute & .63686719 \\
Differences & Positive & .093 \\
& Negative & .093 \\
Kolmogorov-Smirnov Z & -.092 \\
Asymp. Sig. (2-tailed) & .826 \\
\end{tabular}

${ }^{\text {a }}$ Test distribution is normal.

Source: SPSS output, processed primary data, 2019

From the result of Kolmogorov-Smirnov test, can be seen that the value of KolmogorovSmirnov is 0.826 and significant at 0.502 . it means that residual data is normally distributed.

The classical assumption tests performed in this study are multicollinearity test and heteroscedasticity test. Multicollinearity test is performed to detect whether there is a 
HOLISTICA Vol 11, Issue 3, 2020, pp.102-119

correlation among independent variables. In this study, multicollinearity test is performed using the analysing correlation matrix among independent variables and computing the Tolerance and Variance Inflation Factor (VIF) value. The result of multicollinearity test can be seen on the following table:

Table 5 The Result of Multicollinearity Test

\section{Coefficients $^{\mathrm{a}}$}

\begin{tabular}{|c|c|c|c|c|c|c|c|}
\hline \multirow{2}{*}{ Model } & \multicolumn{2}{|c|}{$\begin{array}{c}\text { Unstandardized } \\
\text { Coefficients }\end{array}$} & \multirow{2}{*}{$\begin{array}{c}\text { Standardized } \\
\text { Coefficients }\end{array}$} & \multirow{2}{*}{$\mathrm{t}$} & \multirow{2}{*}{ Sig. } & \multicolumn{2}{|c|}{$\begin{array}{c}\text { Collinearity } \\
\text { Statistics }\end{array}$} \\
\hline & B & $\begin{array}{l}\text { Std. } \\
\text { Error }\end{array}$ & & & & Tolerance & VIF \\
\hline 1 (Constant) & $\begin{array}{c}- \\
1.508\end{array}$ & .440 & & -3.430 & .001 & & \\
\hline AVEOPC & .115 & .132 & .084 & .877 & .383 & .658 & 1.520 \\
\hline AVEAB & 1.155 & .162 & .683 & 7.135 & .000 & .658 & 1.520 \\
\hline
\end{tabular}

Source: SPSS 16 output, processed primary data, 2019

The general cut-off values to indicate the multicollinearity problems are: Tolerance value $\leq 0.10$ and VIF value $\geq 10$ (Ghozali, 2011). From the table above, it can be seen that no independent variable with Tolerance value less than 0.10 , it can be concluded that no correlation among independent variables with more than $95 \%$ value. The computation of VIF value also indicate that there are no variables with VIF value more than 10 , so it can be concluded that there is no multicollinearity among the variables.

Heterocedasticity test is performed to test whether in the regression model there is a variance inequality from one observation to another (Ghozali, 2011). Heterocedasticity test in this study is performed using the Glejser test, and the resuld can be seen in the following table:

Table 6 The Result of Heteroscedasticity Test

\begin{tabular}{|c|c|c|c|c|c|}
\hline \multicolumn{6}{|c|}{ Coefficients $^{a}$} \\
\hline \multirow[t]{2}{*}{ Model } & \multicolumn{2}{|c|}{$\begin{array}{l}\text { Unstandardized } \\
\text { Coefficients }\end{array}$} & \multirow{2}{*}{$\begin{array}{c}\begin{array}{c}\text { Standardized } \\
\text { Coefficients }\end{array} \\
\text { Beta }\end{array}$} & \multirow[t]{2}{*}{$\mathrm{t}$} & \multirow[t]{2}{*}{ Sig. } \\
\hline & B & Std. Error & & & \\
\hline 1 (Constant) & .447 & .233 & & 1.920 & .059 \\
\hline AVEOPC & .018 & .070 & .037 & .261 & .795 \\
\hline AVEAB & .009 & .086 & .015 & .104 & .918 \\
\hline
\end{tabular}

a Dependent Variable: AbsUt

Source: SPSS 16 output, processed primary data, 2019 
From the table, it can be seen that both of independent variables (OPC and auditor burnout) have the significance value of 0.795 and 0.918 , respectively. It can be concluded that no independent variables significantly affect the dependent variables. It means that there is no heteroscedasticity problem in regression model.

\subsection{Goodness of Fit Test}

The F Statistic-value test is used to indicate whether all of independent variables included in model will affect the dependent variable simultaneously and to indicate whether regression model can be used to predict dependent variable (Ghozali, 2011). The result of $\mathrm{F}$ - value test in this study can be seen in the following table:

Table 7 Goodness of Fit Test

\begin{tabular}{cccccc}
\hline \multicolumn{5}{c}{ ANOVA $^{\mathrm{b}}$} \\
\hline Model & $\begin{array}{c}\text { Sum of } \\
\text { Squares }\end{array}$ & Df & $\begin{array}{c}\text { Mean } \\
\text { Square }\end{array}$ & $\mathrm{F}$ & Sig. \\
\hline 1 Regression & 37.320 & 2 & 18.660 & 44.826 & $.000^{\mathrm{a}}$ \\
Residual & 31.637 & 76 & .416 & & \\
Total & 68.957 & 78 & & & \\
\hline a Predictors: (Constant), AVEAB, AVEOPC & & & \\
${ }^{\mathrm{b}}$ Dependent Variable: AVEDAB & & & & \\
\hline
\end{tabular}

Source: SPSS Output, Processed primary data, 2019

From the table above, it can be seen that $F$-value is 44.826 with significance value of 0.000 $(<0.05)$. It can be concluded that in this study, organizational - professional conflict and auditor burnout as independent variables simultaneously affect the dysfunctional audit behaviour as dependent variable. Or similarly, it can be concluded that the regression model can be used to predict dysfunctional audit behaviour.

\section{Analysis and Interpretation}

\subsection{Respondent Demography}

In this study, 36 (thirty-six) auditors as the respondents ( $45.57 \%$ respondents) are male auditor and the rest of 43 (forty-three) auditors (54.43\% respondents) are female auditors. Most of the respondents are in the $25-30$ years old age range (around $37.97 \%$ respondents), has just held undergraduate education (around $79.75 \%$ respondents) and have not held professional certification (around $72.15 \%$ respondents). Moreover, most of the respondents are junior and senior auditors (around $43.04 \%$ and $45.57 \%$ respondents, 
HOLISTICA Vol 11, Issue 3, 2020, pp.102-119

respectively) and has less than two years of work experience (around $41.77 \%$ respondents). The detail of respondent demography can be seen on this following table:

Table 8 Respondent Demography

\begin{tabular}{|c|c|c|c|c|}
\hline No & $\mathrm{De}$ & scription & Amount & Percentage \\
\hline \multirow[b]{2}{*}{1} & \multirow{2}{*}{ Gender } & Male & 36 & 45.57 \\
\hline & & Female & 43 & 54.43 \\
\hline & Total & & 79 & 100 \\
\hline \multirow{10}{*}{2} & \multirow{9}{*}{ Age } & Less than 25 years old & 29 & 36.71 \\
\hline & & 25 - 30 years old & 30 & 37.97 \\
\hline & & 31 - 35 years old & 14 & 17.72 \\
\hline & & 36 - 40 years old & 3 & 3.80 \\
\hline & & 41 - 45 years old & 2 & 2.53 \\
\hline & & 46 - 50 years old & 1 & 1.27 \\
\hline & & 51 - 55 years old & 0 & 0.00 \\
\hline & & 56 - 60 years old & 0 & 0.00 \\
\hline & & More than 60 years old & 0 & 0.00 \\
\hline & Total & & 79 & 100 \\
\hline \multirow{5}{*}{3} & \multirow{4}{*}{ Professional Certification } & Only CPA & 14 & 17.72 \\
\hline & & CPA and Others (CMA, etc.) & 3 & 3.80 \\
\hline & & Other Professional Certification & 5 & 6.33 \\
\hline & & No Professional Certification & 57 & 72.15 \\
\hline & Total & & 79 & 100 \\
\hline \multirow{4}{*}{4} & \multirow{3}{*}{ Education } & Undergraduate & 63 & 79.75 \\
\hline & & Master & 16 & 20.25 \\
\hline & & Doctoral & 0 & 0.00 \\
\hline & Total & & 79 & 100 \\
\hline \multirow{5}{*}{5} & \multirow{4}{*}{ Audit Experience } & Less than 2 years & 33 & 41.77 \\
\hline & & 2 - 5 years & 25 & 31.65 \\
\hline & & 5 - 10 years & 20 & 25.32 \\
\hline & & More than 10 years & 1 & 1.27 \\
\hline & Total & & 79 & 100 \\
\hline \multirow{3}{*}{6} & \multirow{3}{*}{ Position } & Junior auditor & 34 & 43.04 \\
\hline & & Senior auditor & 36 & 45.57 \\
\hline & & Assistant Manager & 0 & 0.00 \\
\hline
\end{tabular}




\begin{tabular}{cccc}
\hline & $\begin{array}{c}\text { Senior Manager } \\
\text { Partner }\end{array}$ & 4 & 5.06 \\
& & 5 & 6.33 \\
\hline Total & & 79 & 100 \\
\hline
\end{tabular}

Source: processed primary data, 2019

\subsection{Descriptive statistics}

Descriptive statistics provide the description of data. It can be seen from mean, standard deviation, variance, maximum and minimum value, sum, range, kurtosis, and skewness (Ghozali, 2011). The descriptive statistics in this study can be seen in the following table:

Table 9 Descriptive Statistics

\begin{tabular}{cccccc}
\hline & N & Minimum & Maximum & Mean & Std. Deviation \\
\hline AVEDAB & 79 & 1.07 & 4.48 & 2.4102 & .94025 \\
AVEOPC & 79 & 2.00 & 5.00 & 3.4599 & .68418 \\
AVEAB & 79 & 1.94 & 4.39 & 3.0457 & .55618 \\
Valid N (listwise) & 79 & & & & \\
\hline
\end{tabular}

Source: SPSS output, processed primary data, 2019

\subsection{Regression Test: The Effect of Organizational Professional Conflict and Auditor Burnout on Dysfunctional Audit Behaviour}

In this study, the effect of organizational - professional conflict and auditor burnout on dysfunctional audit behaviour is identified by performing regression test. Based on Ghozali (2011), it is explained that regression analysis does not only measure the strength of the relationship among variables, but also shows the direction of the relationship among independent and dependent variables (positive effect or negative effect). Furthermore, in this study, the result of the regression test can be seen on the following table:

Table 10 Regression Test Results

\begin{tabular}{|c|c|c|c|c|c|c|c|}
\hline \multirow{3}{*}{ Model } & & & \multicolumn{5}{|l|}{ Coefficients $^{a}$} \\
\hline & \multicolumn{2}{|c|}{$\begin{array}{c}\text { Unstandardized } \\
\text { Coefficients }\end{array}$} & \multirow{2}{*}{$\begin{array}{c}\begin{array}{c}\text { Standardized } \\
\text { Coefficients }\end{array} \\
\text { Beta }\end{array}$} & \multirow{2}{*}{$\mathrm{t}$} & \multirow{2}{*}{ Sig. } & \multicolumn{2}{|c|}{$\begin{array}{c}\text { Collinearity } \\
\text { Statistics }\end{array}$} \\
\hline & B & Std. Error & & & & Tolerance & VIF \\
\hline 1 & -1.508 & .440 & & - & .001 & & \\
\hline (Constant) & & & & 3.430 & & & \\
\hline AVEOPC & .115 & .132 & .084 & .877 & .383 & .658 & 1.520 \\
\hline
\end{tabular}




\begin{tabular}{cccccccc}
\hline AVEAB & 1.155 & .162 & .683 & 7.135 & .000 & .658 & 1.520 \\
\hline${ }^{a}$ Dependent Variable: AVEDAB & & & & & & &
\end{tabular}

Source: SPSS output, processed primary data, 2019

From the table above, it can be seen that:

a. The significance value of organizational - professional conflict shows the result of 0.383. The significance value shown in the regression model is more than $0.05(>0.05)$. It indicates the value is not significant, so that $\mathrm{H} 1$ is not supported. Thus, it can be concluded that in this study, organizational professional conflict as independent variable did not affect the dysfunctional audit behaviour. This condition may be caused by the experience background of respondents itself. As mentioned in the respondent demography, it is said that most respondents are junior and senior auditor. In this condition, some of the respondents may not have any concern yet regarding the professional and organizational value. In the other hand, those junior and senior auditors as respondents may not experience any conflict since they may discuss with their manager on the higher position in case, they face any kind of conflict regarding professional and organizational value.

b. The significance value of auditor burnout shows the result of 0.000 . The significance value shown in the regression model is more than $0.05(<0.05)$. It indicates the value is significant, so that $\mathrm{H} 2$ is supported. Thus, it can be concluded that in this study, auditor burnout as independent variable positively affects the dysfunctional audit behaviour. This finding in this study is similar with the previous studies (Mcnamara \& Liyanarachchi, 2008; Coram, et.al., 2004 as cited in Umar, et.al, 2017; Yuen, et.al, 2013) that explained that stressor has an impact to acceptance of dysfunctional audit behaviour.

\section{Conclusions}

\subsection{Research Conclusion and Implication}

From the regression test, we can conclude that: 1 ) The result in this study indicates that $\mathrm{H} 1$ is not supported. It can be concluded that organizational - professional conflict has no effect on dysfunctional audit behaviour. 2) In this study, the result indicates that $\mathrm{H} 2$ is supported. Auditor burnout has positive effect on dysfunctional audit behaviour. It means that the auditors will tend to do the dysfunctional audit behaviour when they are in the condition of job burnout. The level higher level of burnout will be occurred when the auditors experience the higher level of job burnout.

The implication in this study is related to the situation of auditor workplace. Since in this study is found that auditor burnout has positive effect on dysfunctional audit behaviour, it may be a concern for the auditor itself and public accounting firm management to their auditors as employees. Since burnout can cause dysfunctional audit behaviour that may reducing the quality of audit performance, it would be better that auditor as individual 
and accounting firm may consider some activities regarding work - life balance or workplace environment in purpose to reduce the job stress in workplace and make the auditor feel comfortable in doing their audit assignment. Approach to deal with this jobstress thing in accounting firm has been recommended in previous study by Gaertner and Ruhe (1981) by dividing it into two strategies: personal and organizational strategies. Personal strategies refer to the strategies that individual can aware and implement in various stress - producing situations by recognizing the symptoms of stress itself: insomnia, depression, irritability, and headaches; so, in these strategies, individuals can consider some activities to manage stress (Gaertner \& Ruhe, 1981). Other strategies as explained by Gaertner and Ruhe (1981) can be maintained in organization level. Some strategies can be implemented by accounting firm for reducing stress in workplace, such as: management education program to identify potential stressful situations, job rotation, and communicating the clear job description to reduce the role ambiguity.

\subsection{Research Suggestion}

This study used organizational - professional conflict and auditor burnout as variables that presumably affect dysfunctional audit behaviour. This study results on conclusion that auditor burnout has positive effect on dysfunctional audit behaviour meanwhile organizational-professional conflict has no effect on dysfunctional audit behaviour. Some suggestions may be implemented for further studies regarding the dysfunctional audit behaviour: a) identifying other factors that may affect dysfunctional audit behaviour; $b$ ) develop the relationship of auditor burnout and dysfunctional audit behaviour by adding moderating variable that considered enhancing the relationship of auditor burnout and dysfunctional audit behaviour (e.g.: variables that may related to the individual characteristics, such as: personality type, gender, etc.); c) modify the current research model to propose another research model using the similar variables, for example: placing auditor burnout as intervening or mediating variable in identifying the relationship of organization - professional conflict on dysfunctional audit behaviour.

\section{References}

Acharya, A., Blackwell, M, \& Sen, M. (2018). Explaining Preferences from Behavior: A Cognitive Dissonance Approach, The Journal of Politics, Vol.80, No. 2: $400-411$.

Aranya, N., \& Ferris, K.R. (1984). A Reexamination of Accountants' Organizational - Professional Conflict, America Accounting Association, Vol. LIX, No. 1: 1-15.

Biddle, B.J. (1986). Recent Developments in Role Theory, Annual Review of Sociology, Vol. 12: 67 $-92$.

Boynton, W.C., \& Johnson, R.N. (2006). Modern Auditing: Assurance Services and Integrity of Financial Reporting. 8th Edition. John Wiley and Sons.

Donnelly, D.P., Quirin, J.J., \& O'Bryan, D. (2003). Auditor Acceptance of Dysfunctional Audit Behavior: An Explanatory Model Using Auditors' Personal Characteristics, Behavioral Research in Accounting, Vol. 15: 87-110.

Gaertner, J.F., \& Ruhe, J.A. (1981). Job-related Stress in Public Accounting: CPAs Who Are Under the Most Stress and Suggestions on How to Cope, Journal of Accountancy, 68-74. 
Ghozali, I. (2011). Aplikasi Analisis Multivariate Dengan Program IBM SPSS 19. 5th Edition. Semarang: Badan Penerbit Universitas Diponegoro.

Harmon - Jones, E., Harmon - Jones, C., \& Levy, N. (2015). An Action-Based Model of CognitiveDissonance Processes, Current Directions in Psychological Science, Vol 24, No. 3: 184- 189.

Huczynzki, A.A., Buchanan, D.A. (2007). Organizational Behavior. 6th Edition. Essex, United Kingdom: Pearson Education, Ltd.

International Standard on Quality Control (ISQC) 1. Accessed December 11th, 2019. https://www.ifac.org/system/files/downloads/a007-2010-iaasb-handbook-isqc-1.pdf.

International Standard on Auditing (ISA) 220. Accessed December 11th, 2019. https://www.ifac.org/system/files/downloads/a010-2010-iaasb-handbook-isa-220.pdf.

Ivancevich, J.M., Konopaske, R., \& Matteson, M.T. (2008). Organizational Behaviour and Management. 10th Edition. New York, NY: McGraw-Hill.

Khan, S., Panatik, S.A.B., \& Saat, M.B. (2015). Dysfunctional Audit Behaviour: An Explanatory Study in Pakistan, Research Journal of Applied Science, Engineering and Technology, Vol. 9, No. 9: $77-785$.

Luthans, F. (2011). Organizational Behavior: An Evidence-based Approach. 12th Edition. New York, NY: McGraw-Hill.

Maslach, C., \& Jackson, S.E. (1981). The Measurement of Experienced Burnout, Journal of Occupational Behaviour, Vol. 2: $99-113$.

Mas'ud, F. (2004). Survai Diagnosis Organisasional. Semarang: Badan Penerbit Universitas Diponegoro.

Paino, H., Thani, A., \& Idris, S.I.Z.S. (2011). Organizational and Professional Commitment on Dysfunctional Audit Behaviour, British Journal of Art and Social Sciences, Vol. 1, No. 2: 94105.

Sekaran, U., \& Bougie, R. (2013). Research Method for Business: A Skill-Building Approach. 6th Edition. Chichester, West Sussex, United Kingdom: John Wiley and Sons, Ltd.

Shafer, W.E., Park, L.J., \& Liao, W.M. (2002). Professionalism, Organizational - Professional Conflict and Work Outcomes: A Study of Certified Management Accountants, Accounting, Auditing, and Accountability Journal, Vol. 15, No. 1: 46-68.

Shafer, W.E. (2002). Ethical Pressure, Organizational - Professional Conflict and Related Work Outcomes Among Management Accountants, Journal of Business Ethics, Vol. 38, No. 3: 261273.

Silaban, A. (2009). Perilaku Disfungsional Auditor Dalam Pelaksanaan Program Audit: Studi Empiris di Kantor Akuntan Publik, Dissertation. Universitas Diponegoro.

Tuanakotta, T. M. (2014). Audit Berbasis ISA. Jakarta: Salemba Empat.

Umar, M., Sitorus, S.M., Surya, R.L., Shauki, E.R., \& Diyanti, V. (2017). Pressure, Dysfunctional Behavior, Fraud Detection, and Role of Information Technology in the Audit Process, Australasian Accounting, Business and Finance Journal, Vol.11, No. 4: 102-115.

Utami, I. (2007). Pengaruh Tekanan Etis Terhadap Konflik Organisasional - Profesional dan Work Outcomes, Jurnal Maksi, Vol. 7, No.1: $1-18$.

Utami, I., \& Nahartyo., E. (2013). The Effect of Type A Personality On Auditor Burnout: Evidence From Indonesia, Accounting and Taxation, Vol. 5, No.2: 89-102.

Weningtyas, S., Setyawan, D., \& Triatmoko, H. (2006). Penghentian Prematur Atas Prosedur Audit, Proceeding: Simposium Nasional Akuntansi IX Padang.

Yuen, D.C.Y., Law, P.K.F., Lu, C., \& Guan, J.Q. (2013). Dysfunctional auditing behaviour: empirical evidence on auditors' behaviour in Macau, International Journal of Accounting and Information Management, Vol. 21, No. 3: $209-226$. 